\title{
Impacts of Oreochromis Nilticus Cage Culture on Water Quality of Winam Gulf of L. Victoria, Kenya
}

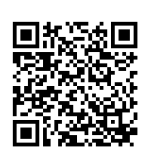

\author{
Steve Omari Ngodhe ${ }^{1 *}$, Okeyo Owuor JB ${ }^{1}$ and Pamela Were ${ }^{2}$ \\ ${ }^{1}$ Rongo University, Kenya \\ ${ }^{2} J a r a m o g i$ Oginga Odinga University of Science and Technology, Kenya
}

Submission: April 24, 2019; Published: May 30, 2019

*Corresponding author: Steve Omari Ngodhe, Rongo University P.O Box 103-40404, Rongo, Kenya

\begin{abstract}
Lake Victoria, Kenya has realized an increased number of fish cage culture for the last 10 years. The water quality monitoring study was undertaken at different private cage fish farm within the Winam gulf of L. Victoria, Kenya. In-situ measurements of key environmental parameters: temperature, dissolved oxygen, $\mathrm{pH}$ and total dissolved solids variables were taken each month for a period of 8 months. Environment parameters did not vary spatially or temporally between the cages and open waters of the gulf and were generally within safe ranges for freshwater habitats. This was attributed to the fact that the study areas were all within the same geographical space and lack of variation in micro-climatic conditions during the study period. The environmental variables were within the National Environmental and Management Authority (NEMA) and the desirable levels for cage culture. The study recommended that the efforts to promote commercial cage culture enterprises in Winam Gulf of $\mathrm{L}$. Victoria and other water bodies should be enhanced on condition that the cages are sited in deep waters of the gulf with low cage concentration in a particular site and reduced stocking densities in order not to compromise the environmental quality, which can cause undesirable changes in natural biological productivity processes.
\end{abstract}

Keywords: Aquaculture; Effects; Environmental variables; L. Victoria; Kenya

\section{Background Information}

To feed a world whose population is expected to grow to 9.6 billion by 2050, current agricultural production from crops, livestock, fisheries and aquaculture must increase by over $60 \%$ [1]. To meet these increasing demands, the contribution from sustainable aquaculture production would be fundamental. Aquaculture farming now represents the fastest growing animal food producing sector of the world, with an annual average growth of $8.6 \%$ over the last decade. The sector also remains an important source of essential nutrients, accounting for over $17 \%$ of the global population's consumption of animal protein [1]. In 2012 , the total global aquaculture production was estimated to be over 90.4 million tons [2] with freshwater fish representing the bulk. In the same year, the total production from inland aquaculture of both herbivorous and omnivorous finfish species was estimated to be 42 million tons [2].

Growing fish in cages has been seen to have the potential for bridging the supply-demand gap. Cage farming is currently practiced in many parts of the world but has in the last 10 years become a popular fish farming practice in many Africa countries Kenya included [3]. In comparison to traditional pond culture systems, the advantage of cage fish culture technology is the possibility of growing a large amount of fish in a relatively small volume or area of water. For instance, in $9-12 \mathrm{~m} 3$ cage, one can raise one ton of fish within a period of 8 months. In the East African region, cage fish farming has not been widely practiced despite a large market for fish in the region and known potential of the practice [3]. Cage fish farming is currently practiced by few commercial fish farmers and is a direct response to declining fish harvests from wild fish stocks and increasing market demand from local, regional and international markets. Kenya is promoting cage fish farming as an avenue for blue economy to improve household incomes and national food security [4].

Studies indicate that fish rearing in cages in natural freshwater water bodies (lakes, rivers, reservoirs and dams) raises concerns of water quality and disease impacts from the caged fish [5] despite the promise for high fish production over relatively short time periods. Other concerns include impacts on biological communities especially in cases of intensive cage culture [6]. Water quality deterioration may result from release of solid wastes [6] such as un-eaten feeds, faeces and mucus, soluble wastes especially phosphorus and nitrogen compounds. Overtime, these may cause environmental impacts such as eutrophication [7,8], algal blooms and changes in zooplankton community structure [6] that may affect natural fish production. Mangaliso et al. [5] predicted that intensive aquaculture is likely to become an important new source of nutrients on local and lake-wide scale. It is therefore important that all projects that involve intensification of aquaculture should be backed by a strong environmental monitoring program. It is because of these concerns that the study developed its main objective of evaluating the possible impacts of cage fish culture on water quality of the Winam Gulf of Lake Victoria, Kenya. 


\section{Materials and Methods}

The study was carried out at Winam Gulf of L. Victoria, Kenya which is a $1400 \mathrm{~km} 2$ large bay with a $550 \mathrm{~km}$ shoreline located entirely in Kenya, in the northeast of Lake Victoria. It is connected to the main basin only by the $3 \mathrm{~km}$ wide Rusinga channel. An even narrower, but deeper channel south of Rusinga Island used to allow for better circulation but was closed by a causeway built in 1980. Average and maximum depth in the
Winam Gulf are $6 \mathrm{~m}$ and $68 \mathrm{~m}$, respectively (Figure 1). Triplicate temperature, dissolved oxygen (DO), total dissolved solid (TDS) and $\mathrm{pH}$ readings were taken in situ by water quality multi-probe meter, (OAKTONR, Model pH/Mv/ ${ }^{\circ} \mathrm{C}$ METER, Singapore) at a depth of $10 \mathrm{~cm}$ below the water surface inside the cage and $1 \mathrm{~km}$ away from the cages. The same measurements were again taken from $10 \mathrm{~m}, 20 \mathrm{~m}$ and $30 \mathrm{~m}$ away from the cages for each of the sampling sites and recorded.

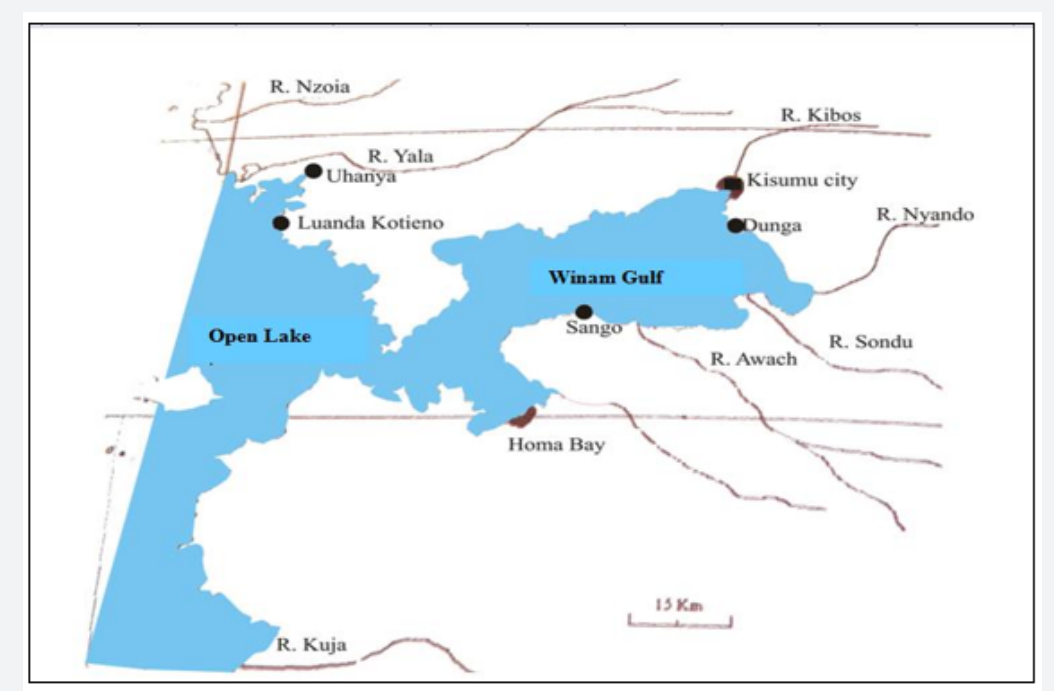

Figure 1: A map showing Winam gulf and major rivers draining into it and the open waters.

Water quality physico-chemical parameters were summarized for the study period as mean \pm SE values for each sampling station. One-way ANOVA and LSD post hoc tests were used to compare mean values.

\section{Results}

The mean monthly physico-chemical water quality parameters at the cages and open waters from the month of January (1) to August (8) 2018 is shown in Table 1. In cages, physico-chemical water quality parameters did not show any significant difference between the sampled months ( $p>0.05)$. The highest temperature was recorded in January with a mean of $26.8 \pm 0.41^{\circ} \mathrm{C}$ and the lowest registered in the month of May with Table 1: Mean Monthly ( \pm SEM) of physico-chemical water quality parameters measured in cages and open waters during the study period.

\begin{tabular}{|c|c|c|c|c|c|c|c|c|}
\hline Month /Site & 1 & 2 & 3 & 4 & 5 & 6 & 7 & 8 \\
\hline \multicolumn{9}{|l|}{ Cage } \\
\hline Temp. & $26.8 \pm 0.41$ & $26.6 \pm 0.39$ & $25.4 \pm 0.46$ & $24.5 \pm 0.38$ & $24.8 \pm 0.29$ & $25.5 \pm 0.42$ & $26.5 \pm 0.35$ & $26.2 \pm 0.45$ \\
\hline Do & $4.4 \pm 0.12$ & $4.1 \pm 0.11$ & $5.6 \pm 0.14$ & $5.3 \pm 0.13$ & $5.1 \pm 0.15$ & $4.9 \pm 0.11$ & $5.2 \pm 0.13$ & $5.3 \pm 0.15$ \\
\hline $\mathrm{pH}$ & $7.2 \pm 0.15$ & $7.1 \pm 0.13$ & $7.3 \pm 0.18$ & $7.1 \pm 0.16$ & $7.3 \pm 0.14$ & $7.1 \pm 0.12$ & $7.1 \pm 0.14$ & $7.1 \pm 0.17$ \\
\hline Sal & $0.12 \pm 0.02$ & $0.12 \pm 0.01$ & $0.14 \pm 0.02$ & $0.12 \pm 0.01$ & $0.13 \pm 0.02$ & $0.14 \pm 0.02$ & $0.14 \pm 0.01$ & $0.14 \pm 0.02$ \\
\hline TDS & $28.8 \pm 0.45$ & $18.4 \pm 0.32$ & $26.4 \pm 0.35$ & $25.5 \pm 0.43$ & $26.5 \pm 0.55$ & $24.5 \pm 0.44$ & $27.5 \pm 0.48$ & $26.6 \pm 0.46$ \\
\hline \multicolumn{9}{|l|}{ Open Waters } \\
\hline Temp. & $26.2 \pm 0.53$ & $26.5 \pm 0.41$ & $26.0 \pm 0.37$ & $26.5 \pm 0.43$ & $25.7 \pm 0.44$ & $25.5 \pm 0.48$ & $25.7 \pm 0.47$ & $25.8 \pm 0.36$ \\
\hline Do & $6.4 \pm 0.15$ & $5.9 \pm 0.11$ & $5.8 \pm 0.14$ & $6.2 \pm 0.16$ & $5.8 \pm 0.17$ & $5.5 \pm 0.12$ & $6.2 \pm 0.18$ & $7.0 \pm 0.15$ \\
\hline $\mathrm{pH}$ & $7.2 \pm 0.16$ & $7.1 \pm 0.13$ & $7.1 \pm 0.12$ & $7.2 \pm 0.10$ & $7.0 \pm 0.12$ & $7.0 \pm 0.15$ & $7.2 \pm 0.13$ & $7.0 \pm 0.13$ \\
\hline
\end{tabular}




\section{International Journal of Environmental Sciences \& Natural Resources}

\begin{tabular}{|c|c|c|c|c|c|c|c|c|}
\hline Sal & $0.14 \pm 0.02$ & $0.14 \pm 0.01$ & $0.12 \pm 0.01$ & $0.13 \pm 0.01$ & $0.13 \pm 0.02$ & $0.14 \pm 0.02$ & $0.14 \pm 0.01$ & $0.14 \pm 0.02$ \\
\hline TDS & $19.3 \pm 0.33$ & $16.8 \pm 0.22$ & $19.5 \pm 0.36$ & $19.5 \pm 0.31$ & $18.5 \pm 0.24$ & $24.0 \pm 0.53$ & $22.5 \pm 0.46$ & $18.6 \pm 0.33$ \\
\hline
\end{tabular}

In the open waters, temperature was highest during the months of January, February, March and April all recorded 26.2 $\pm 0.53,26.5 \pm 0.41,26.0 \pm 0.37$ and $26.5 \pm 0.43 \stackrel{\circ}{\circ} \mathrm{C}$ respectively and the lowest were recorded in the rest of the months where the mean values were all $25^{\circ} \mathrm{C}$. Concentrations of DO almost follow a similar trend but only that the highest was recorded in the month of August with a mean of $7.00 \pm 0.15 \mathrm{mg} / \mathrm{l}$ and the lowest recorded during the month of June with a mean of $5.5 \pm 0.12 \mathrm{mg} / \mathrm{l}$. $\mathrm{pH}$ had a range between 7.00 in the months of May, June and August and 7.20 in the months of January, April and July. TDS concentration was highest in the month of June recording a mean of $24.0 \pm 0.5 \mathrm{mg} / \mathrm{l}$ and lowest in February recording a mean of $16.8 \pm 0.22 \mathrm{mg} / \mathrm{l}$. Just like in the cage, the open waters also showed no statistical difference in the physico-chemical water quality parameters between the months during the study period ( $p>0.05$ ) (Table 1). The mean monthly concentrations of environmental variables did not show a significant difference between the cage and the open waters ( $p>0.05)$.

Results showed that ranges of selected water environment variables (Table 2) across the sampling areas were compared with the desirable levels for cage culture from literature (Table 2).

Table 2: Common physico-chemical values (mean $\pm \mathrm{SE}$ ) of the study sites and desirable levels for cage culture.

\begin{tabular}{|c|c|c|c|}
\hline Parameters & Cage & Open Waters & Desirable Levels for Cage Culture \\
\hline Temp.(0C) & $25.9 \pm 0.67$ & $26.5 \pm 0.65$ & $12-30[9]$ \\
\hline DO (mg/l) & $4.98 \pm 0.20$ & $5.98 \pm 0.96$ & $>3[10]$ \\
\hline PH & $7.17 \pm 0.35$ & $7.09 \pm 0.39$ & $6-9[11]$ \\
\hline TDS (mg/l) & $25.5 \pm 0.85$ & $19.4 \pm 0.98$ & - \\
\hline
\end{tabular}

In order to assess the spatial effect of cage on physicochemical water quality parameters, the measurements were also taken at 10, 20 and $30 \mathrm{~m}$ away from the cage. Temperature recorded a slight variation between inside cage and outside the cage. Inside cage had a mean temperature of $25.9 \pm 0.670 \mathrm{C}$ while the outside recorded a uniform temperature of $27.1 \pm 0.82$, $27.2 \pm 0.65$ and $27.0 \pm 0.780 \mathrm{C}$ at 10,20 and $30 \mathrm{~m}$ respectively. There was a very low significant difference between the inside and outside cage $(\mathrm{p}=0.04)$. The same trend was shown in DO concentration where inside cage had a mean of $4.98 \pm 0.20 \mathrm{mg} / \mathrm{l}$ while outside had $5.80 \pm 0.96,6.00 \pm 0.76$ and $6.1 \pm 0.84 \mathrm{mg} / \mathrm{l}$ at 10 ,
20 and $30 \mathrm{~m}$ respectively. There was a low significant difference between the inside and outside cage $(p=0.04)$. There was no statistical difference between inside and outside the cage in $\mathrm{pH}$ values $(\mathrm{p}=0.15)$. Inside cage had $7.17 \pm 0.35$ while outside cage recorded $7.08 \pm 0.31,7.09 \pm 0.25$ and $7.14 \pm 0.28$ at 10,20 and $30 \mathrm{~m}$ respectively. TDS was higher inside the cage $(25.49 \pm 0.85 \mathrm{mg} / \mathrm{l})$ than outside. There was a mean of $22.0 \pm 0.65,20.0 \pm 0.39$ and $20.5 \pm 0.45 \mathrm{mg} / \mathrm{l}$ at 10,20 and $30 \mathrm{~m}$ respectively. There was a significant statistical difference in temperature between the inside and mean outside the cage $(\mathrm{p}=0.03)$ (Figure 2).

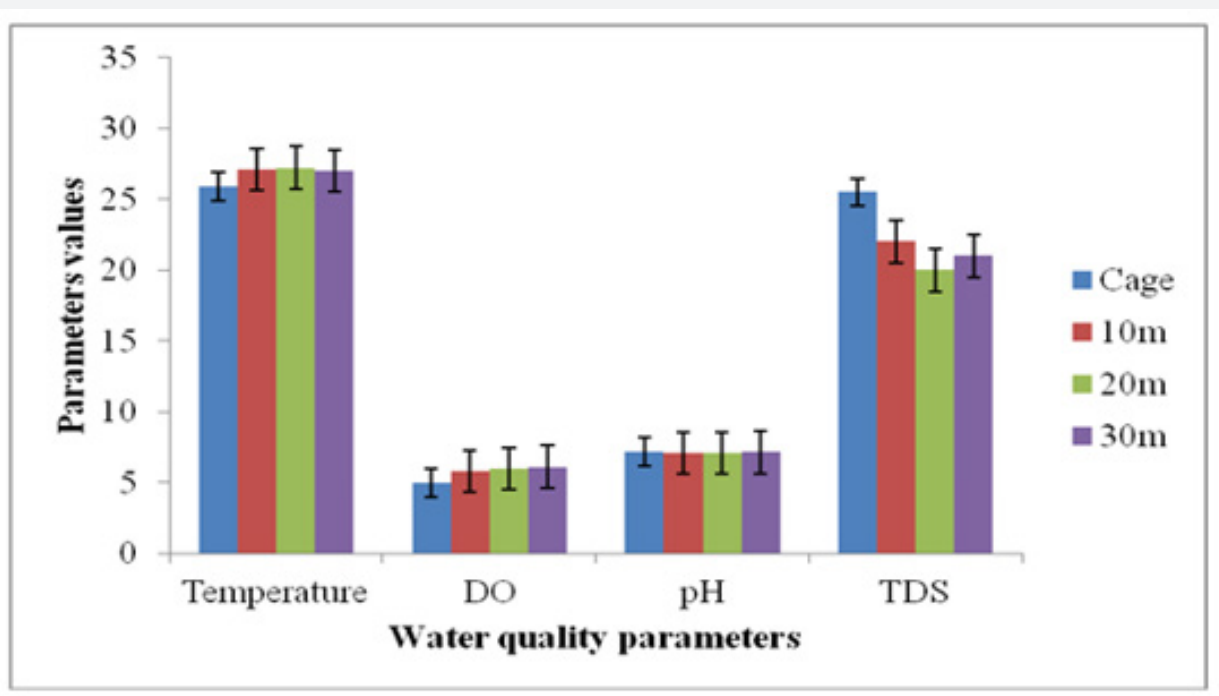

Figure 2: Mean Variations in water quality physico-chemical parameters inside the cages, 10, 20 and 30m away from cage during the study period. 


\section{Discussion}

Measured ranges of selected environmental variables were generally within acceptable levels of National Environmental Management Authority (NEMA), cage culture and freshwater habitats in general. There was no clear evidence of impact of fish cages on any of the measured environmental variable. This could be attributed to the low number of cages per unit area within the gulf. This allows for maximum dilution of fish wastes which would otherwise compromise the physicochemical and biological properties of water. The shallowness of the gulf also renders it prone to stirring of the water by winds causing nutrients to be released from the sediments into the water thus leading to increased productivity [12]. This study is in line with Mkare et al. 2010 who found out that shallow, tropical water bodies are often characterized by homogeneity in physico-chemical parameters due to complete mixing within the water column. Other factors could be due to similarity of micro-climatic conditions within the gulf hence uniform ecological conditions, most of the cages have been within the gulf for a period of less than 3 years and therefore the amount of wastes accumulated is too low to impact on the water quality hence favoring the aquatic biota. Environmental variables changes could negatively affect the aquatic biota as indicated by Holmer [13] who observed that temperature fluctuation affects the development of natural food sources of fish such as phytoplankton and zooplankton hence impacting negatively to fish productivity. High temperatures in any aquatic ecosystem lead to increase in metabolic activity of aquatic organisms and at the same time reduces the concentration of dissolved oxygen in water [14]. The recommended ranges for good performance of warm water fish according to FAO [15] is between 25 and 320C. Very low temperatures causes stagnation of fish growth and at times fish kill and very high temperatures also reduces the solubility of atmospheric oxygen and enhances the fish stress which may lead to fish death. Agricultural practice has been shown to influence nutrients hence affecting the concentrations of $\mathrm{pH}$ and total dissolved solids (TDS) in water and since there is lack of fertilization on agricultural lands surrounding the gulf, their concentrations remain very uniform.

Observations on spatial-temporal variation of dissolved oxygen and total dissolved solids when the measurements were taken from 10, 20 and $30 \mathrm{~m}$ away from the cages suggested minimal impacts from the fish cages despite the proximity to the cages. This was still attributed to low concentration of cages within the entire gulf. Guo \& Li [16] working in L. Niushanhu, China observed that most environmental impacts in cage fish farm areas are associated with increased nutrient inputs although the contribution from other sources such as soil erosion may also be important. Results of the present study appear to have been influenced by water currents constantly sweeping across the study area given the location of the gulf as several rivers drain into it. It is also important to note that released soluble nutrients may be readily taken up by green micro-plants (algae) in the water.

\section{Conclusion}

Results from the study showed no worrying effects of the fish cage facility on selected physical-chemical parameters within the gulf and therefore, current efforts to promote commercial cage fish culture enterprises in Lake Victoria, Kenya and other water bodies should proceed with caution especially regarding site location and concentration of cages at any one site; in order not to compromise the water environment quality, which can cause undesirable changes in natural biological productivity processes. In any case, regular environmental monitoring programs must be strictly enforced for all cage fish culture enterprises.

\section{Acknowledgement}

The authors wish to thank National Research Fund for funding this study and Department of Fisheries and Aquatic Sciences of University of Eldoret for provision of both laboratory space and technical support during the entire study period.

\section{References}

1. FAO (2014) The state of world fisheries and aquaculture 2014. Rome, Italy: FAO Fisheries Department, Fishery Information, Data and Statistics Unit.

2. FAO (2016) The state of world fisheries and aquaculture 2016. Contributing to food security and nutrition for all. Rome, Italy: FAO, pp. 200.

3. Blow P, Leonard S (2007) A review of cage aquaculture: sub-Saharan Africa. In: Halwart M, Soto D, Arthur JR (Eds.), Cage aquaculture Regional reviews and global overview. Rome, Italy. FAO Fisheries Technical paper No. 498. Rome, Italy, FAO. 2007, P. 241.

4. Mbugua HM (2011) A Comparative Economic Evaluation of Farming of Three Important Aquaculture Species In Kenya. Blackwell Publishing, United Kingdom.

5. Mangaliso JS, Guilford SJ, Hecky RE (2011) Physical-chemical measurements in the water column a long a transect through a tilapia cage fish farm in Lake Malawi, Africa. Journal of Great Lakes Research 37(Supp 1): 102-113.

6. Dias JD, Takahashi EM, Santana NF, Bonecker CC (2011) Impact of fish cage-culture on the community structure of zooplankton in a tropical reservior. Iheringia Serie Zoologia 101(1-2): 75 - 84.

7. Demir N, Kirkagac MU, Pulatsü S, Bekcan S (2001) Influence of trout cage culture on the water quality, plankton and benthos in an Anatolian Reservoir. Israeli Journal of Aquaculture 53(3-4): 115-127.

8. Veenstra J, Nolen S, Carroll J, Ruiz C (2003) Impact of net pen aquaculture on lake water quality. Water Sci Technol 47(12): 293-300.

9. Joseph KB, Richard WS, Daniel ET (1993) An introduction to water chemistry in freshwater aquaculture, University of Massachusetts. Dartmouth North D a r t m o u t h Massachusetts. 02747. NRAC Fact Sheet No. 170-1993 pp. 1-4.

10. Delong DP, Losordo TM, Rakorcy JE (2009) Tank culture of Tilapia. Southern Regional Aquaculture Center (SRAC Publication No. 2082).

11. Nathan S, Jay LS, Brian EH, Hugh KT (2013) Interpretation of Water Analysis. Reports for Fish Culture. Southern Regional Aquaculture Centre, SRAC Publications No. 4606, pp. 1-12. 
12. Zanatta AS, Paerbiche-Neves G, Ventura R, Ramos IP, Carvalho ED (2010) Effects of a small fish cage farm on zooplankton assemblages (Cladocera and Copepoda: Crustacea) in a sub-tropical reservoir (SE Brazil). Pan-American. Journal of Aquatic Sciences 5(4): 530-539.

13. Holmer M (2010) Environmental issues of fish farming in offshore waters: Perspectives, concerns and Research needs. Aquaculture Environment Interaction 1: 57-70.

14. Sures B (2008) Environmental parasitology. Interactions between parasites and pollutants in the aquatic environment. Parasite 15(3): 434-438.
15. FAO (2010) Capture Production 1950-2008: FAO Fisheries Department Fishery Information, Data and Statistics Unit. Food and Agriculture Organization of the United Nations, Rome.

16. Guo L, Li Z (2003) Effects of Nitrogen and phosphorus from fish cage culture on the communities of a shallow lake in middle Yangtze River basin of China. Aquaculture 226(1-4): 201-212.

Your next submission with Juniper Publishers will reach you the below assets

- Quality Editorial service

- Swift Peer Review

- Reprints availability

- E-prints Service

- Manuscript Podcast for convenient understanding

- Global attainment for your research

- Manuscript accessibility in different formats (Pdf, E-pub, Full Text, Audio)

- Unceasing customer service

Track the below URL for one-step submission https://juniperpublishers.com/online-submission.php 